\title{
R.L. Stevenson's Outlook on Life as reflected in Virginibus Puerisque
}

\author{
Dr. Poorva Bhonde \\ (Dept. of English) Sharadchandra Arts \& Commerce College, Butibori Nagpur ( M.S ) - India
}

\begin{abstract}
Robert Louis Stevenson (1850-1894) was a brave, cheery and wholesome spirit. He made all his readers braver and cheerier by his writing. This well-known and well-loved Victorian litterateur gave his valuable contribution to English Literature by writing novels, travelogues, poems, short stories and essays.

The love of action and energetic life were deeply ingrained in him. With his novels full of romance and adventure he satisfied the national craving during the period of gloom. His life was a perpetual struggle against an incurable malady. It was nothing but a respite won from death. Yet he had not given way to despair. On the contrary, as life slipped from him, he laid hold on it with redoubled strength. Optimist to the fingertips, he wrote for the young, for readers who love tales of travel and adventure better than morbid analysis of mind.

In addition to imaginative work Stevenson produced a number of essays on morals and literature. His essays with their often very personal note, endeared him to a wide circle of readers. They show the charm, the vivacity and the gaity. His collection of essays Virginibus Puerisque is a delightful, intimate and self-revelatory book. Published in 1881. The themes he his handled in Virginibus Puerisque.as varied as childhood, youth, old age, travel, walking tours, idleness, bravery, courage, death etc. An attempt has been made in the present paper to analyze and interpret Stevenson's Outlook on Life as reflected in the two essays in Virginibus Puerisque: Child's Play and Crabbed Age and Youth.
\end{abstract}

\section{Stevenson's Outlook on life}

'Life' - a four lettered word brings so much in its sphere that its limits seem unlimited. Human life, particularly, has always been a 'piped piper' that attracts a race of interpreters - the philosophers, writers, poets, by the mesmerizing tune of his pipe, leading them into the trap already set. Only a fortunate few, gifted with maturity, courage and insight manage to come out of the trap to tell the world what 'life' actually is! One amongst these gifted interpreters was 'Robert Louis Stevenson'.

Stevenson's outlook on life is very clear. It is mostly reflected in his essays. Whatever he has seen and experienced throughout life, he has tried to put forth for our consideration whereby human beings can decide their way of living and exercise the maximum pleasure in life.

Through his essays Stevenson broods upon different stages of human life - childhood, youth, old age, and the end of all - Death. His tireless pen touches different aspects of human life so powerfully \& skillfully that one falls in love not only with the writings but also with the writer. And what a man he was! Optimist to the core! Never to be intimidated by death! How full of sunshine his thoughts - even the depressed ones feel like coming out of the dark chamber of mind to bathe in it.

Stevenson's outlook on life is so beautifully interwoven in the compact design of his essays in 'Virginibus Puerisque', that it is sheer pleasure to study them to understand his philosophy.

Stevenson's outlook on childhood finds its reflection in his essays. For a child, life is like a Kaleidoscope. Patterns and designs of life keep changing every minute. They live in the world of their own. They can tolerate or rather neglect all the incongruities. They have strange power of imagination. Play is everything for the child. He puts it even above the realities. He is not so much interested in those real things which he imitates as his imitation. Believing everything is the motto of his life. So much so that he rarely does anything for himself or directly. He always imagines something and then works under that deception. Even in eating they can take interest only when they convert it into a game or something else by their imagination and then it is the game that they are interested in the meals. The same is their attitude about games. That game which cannot be translated into fable and of which no stories can be told, finds no favour with them.

Showing deep understanding of Child Psychology Stevenson writes, "One thing, at least, comes very clearly out of these considerations : that whatever we are to expect at the hands of children, it should not be any peddling exactitude about matters of fact. They walk in a vain show, and among mists and rainbows; they are passionate after dreams and unconcerned about realities ${ }^{1} . "$

Child sees very little but he is swift to weave what he has seen into bewildering fiction. He cares no more for truth than a gingerbread dragoon. 
Stevenson's own childhood is reflected in some of his autobiographical essays like 'Random Memories'. His mature views on childhood have sprung out of his own experiences as a child. It is here that he concludesthe child is not the man's father, but the man. - as he shows some signs of grown up man in the period of childhood. When Stevenson was a child, his nurse used to read out to him verses from Bible. She also read out verses from Rev. Robert Murray. Stevenson loved to hear them read out by his nurse. Some verses left a lasting impression on his mind. So it is in childhood that man gets prepared unconsciously, for the battle and struggle ahead. But the parents are advised - not to put much restriction on the childhood. After all they have to come to the realm of reality later on.

"In the child's world of dim sensation, play is all in all. 'Making believe' is the gist of his whole life." Their world is different from the world of their parents. A grown up mind cannot indulge into fancy so freely and completely. The truth that the adults value, a child does not, just as adults do not value child's plays and fancies". ${ }^{2}$

So, to put in nutshell Stevenson's outlook on childhood it can be very well said that on the whole Stevenson has not made the difference between childhood and manhood but he has pointed out the subtleties of childhood. How the parents' relation and understanding regarding child should be is what he wants to convey. If his precept is accepted, it would be easy to lighten up the most beautiful period of life.

Stevenson's philosophical reflection finds full view in every line of 'Child's Play' - There would be no piece of better advice for parents than this -

"It would be easy to leave them( children ) in their native cloud-land, where they figure so prettily - pretty like flowers and innocent days. They will come out of their gardens soon enough, and have to go into offices and the witness box. Spare them yet a while, $O$ conscientious parents; let them doze among their play-things yet a little; for who knows what a rough warfaring existence lies before them in the future?"3

Combination of wisdom and action is needed to lead a successful human life. Unfortunately, old age, though rich in wisdom lacks in action. For this very reason, Stevenson finds 'Youth' to be a golden period to make significant achievements in life. Though Stevenson did not live to be an old man, his flashes of insight regarding old age not only amuse and teach but also compels the readers to brood and introspect about the illusions of youth and the disenchantments of the old age.

Stevenson's life set a standard, particularly for the adventurous, the courageous and the young. Inspire of his illness, he kept the animal spirits alive and exhorted the young to lead the life of courage and adventure. He defended the young, particularly the adventurous young. He regarded youth with more affection and less condescension than did almost any other English writer. Famous poet Browning in his poem 'Rabbi Ben Ezra' said,

"Grow old along with me

The best is yet to be"

But Stevenson believed that the period of youth is the golden period in man's life. Shakespeare also expressed the same view in 'The Passionate Pilgrim',

"Age I do abhor thee, youth I do adore thee".

Again, in the same poem Shakespeare wrote,

"Crabbed age and youth cannot live together

Youth is full of pleasure, age is full of care".

Stevenson says that the sayings and proverbs which discourage persons from ambitious attempts are meant for the use of mediocre people. Citing the examples of Joan of Arc and Columbus Stevenson appreciates the untrodden path chosen by the adventurous spirits. For him it is better to gallop up and down the bombshells like the generals than to read the stories of bravery idly at home.

Youth and age are the inevitable stages on the way of life. Everyone, passing on the way must pay due respect to them for they have their own glories. Reflecting this sense he writes,

"Because I had reached Paris, I am not ashamed of having passed through Newhaven and Dieppe. They were good places to pass through, and I am none the less at my destination". ${ }^{4}$

Life is always in flux of change. One should accept the change whole heartedly. If nothing remains the same, why do we regret the change in opinions at different stages of life. Stevenson himself was a socialist once. With years he turned Conservative. He accepts the change without regret, "Now I know that in thus turning Conservative with years, I am going through the normal cycle of change and travelling in the common orbit of men's opinions". ${ }^{5}$ Life would have been better if all the changes are accepted without making much ado about them.

\section{Criticizing the unnecessarily fast-paced life, he writes,}

"If we had breathing space, we should take the occasion to modify and adjust; but at this breakneck hurry, we are no sooner boys than we are adults, no sooner in love than married or jilted, no sooner one age than we begin to be another, and no sooner in the fulness of our manhood than we begin to decline towards our 
grave. It is in vain to seek for consistency or expect clear and stable views in a medium so perturbed and fleeting". 6

All our attributes are modified or changed. Views at forty are not the same as they were at twenty. Remaining the same is akin to the condition of an unteachable brat, who is well birched and none the wiser. "It is as if a ship captain should sail to India from the Port of London; and having brought a chart of Thames on deck at his first setting out should obstinately use no other for the whole voyage". 7

Life, it lead with too much caution becomes dull and dreary. Depriving ourselves of the pleasures today for the pleasurable tomorrow is not advisable as life is uncertain. We do not know when the Arch Rival will snatch it away from us.

"To be suddenly snuffed out in the middle of ambitious schemes, is tragical enough at best; but when a man has been grudging himself his own life in the meanwhile, and saving up everything for the festival that never to be, it becomes that hysterical sort of tragedy which lies on the confines of farce". ${ }^{8}$

How can we compliment a hungry man, who refuses a whole dinner and reserves all his appetite for the dessert, before he knew whether there was to be any dessert or not? Indeed it is the present that matters the most for Stevenson.

His philosophy sounds very practical when he says, "Childhood must pass away; and, then youth, as surely age approaches. The true wisdom is to be always seasonable, and to change with a good grace in changing circumstances. To love play things as well as child, to lead an adventurous and honourable youth, and to settle when the time arrives, into a green and smiling age, is to be a good artist in life and deserve well of yourself and your neighbour." 9

Undying hope is the co-ruler of the human bosom. Whole truth can never be extracted. Every question has two sides and both are right. So very complex is life's sphere that it has its centre everywhere. It is only "one undisturbed song of pure consent" to which we are ever likely to lend our musical voices.

Stevenson always felt that there must be reconciliation in the youth and elder people. Adjustment is the source of happiness. How one adapts oneself to the changing situation reflects his wisdom. Stevenson's outlook on childhood has its roots in his tormented life. Learning the art of living to make life rich and prosperous is what he preaches. He also points out that there should not be quarrel and desperation in the different moods of the youth and the old age because they are the same persons who are struggling to live the life, and putting forth their own way to imitate succeeding generation. To bring out satisfaction to whole mankind, perhaps, this message of Stevenson- of adjustment and reconciliation with old and new is a proper consolation.

[1]. Child's Play, VirginibusPuerisque, P. 144

\section{References :-}

[2]. ibid, P. 141

[3]. ibid, P. 146

[4]. Crabbed Age and Youth,. VirginibusPuerisque, P. 52

[5]. ibid, P. 52

[6]. ibid, P. 54

[7]. ibid, P. 54

[8]. ibid, P. 56

[9]. ibid, P. 60 